\title{
4
}

\section{On cultural factors and Marine Managed Areas in Fiji}

\author{
Joeli Veitayaki, Akosita D.R. Nakoro, Tareguci Sigarua and Nanise Bulai \\ International Ocean Institute, School of Islands and Oceans, University of the South Pacific, Fiji
}

\section{Introduction}

Marine Managed Areas (MMAs) are spreading rapidly in Fiji and other countries in the AsiaPacific region as local communities act to protect their marine resources that are in danger of depletion and overexploitation. Customary practices are the basis of these community-based resource management activities. This creates the need to better understand both the influence of cultural roles on the effectiveness of MMAs and how traditional practices can address the challenges faced today and in the years to come.

In Fiji, many local communities have demonstrated their commitment to manage their marine resources by using their customary rights to declare nearly all of the existing MMAs. In this case, the customary owners of the resources have shown more commitment to manage their resources than the Fiji Government, which pledged at the 2005 Mauritius Meeting of Small Island Developing States to manage 30\% of its national waters by 2020 . It is obvious that local communities have been more adept at making the hard decisions to restrict, reduce and manage their coastal resources for contemporary and future generations. The challenge is to support these community initiatives to effectively conserve their resources for the benefit of the communities and the resource users, as well as the environment.

The intimate relationship between the people in the Pacific Islands and their natural resources demonstrates the care that Pacific Islanders have for each other, future generations and the environment (Govan 2009:22). In these islands, community-based resource management is a dynamic system of social interventions, shaped by local practices and influenced by a combination of internal and external events. Aware that their resources recover quickly if their use is reduced, islanders have developed practices to restrict collecting, gleaning and fishing when it is justified. This is where people's knowledge, education, belief, community dynamics and perceptions influence their resource-management activities. Hence, for more effective contemporary community-based marine-resources management, the people's motives, ethics, interests and cultural conceptions need to be assessed and evaluated.

A customary marine tenure system based on local autonomy and self-reliance controls 
the use of marine space and resources in Fiji and many Pacific Island countries. While this tenure system is recognised in national constitutions and legislation in Papua New Guinea, the Solomon Islands, Samoa and Vanuatu, it is only an informal right in Fiji, which has 410 registered customary fishing rights areas (qoliqoli) that support the subsistence fishers as well as some commercial interests. In the heavily exploited qoliqoli, resource management is critical because local fishing pressure is no longer sustainable (Muehlig-Hofmann 2008).

The declaration of MMAs is determined by the social structure and circumstances of each community. In communities where there is strong, wise and respected leadership (MuehligHofmann 2008), the customary system is offering an alternative to contemporary governmentinstigated resource management. This is important because these traditional communities have committed to manage their resources instead of waiting for government directive, guidance and leadership. However, respect for traditional chiefs, which is now dependent on their strength of character, knowledge and authority (Vunisea 2002), is important for the success of MMAs.

This paper is based on a Conservation International (CI) study that examines how cultural roles affect the effectiveness of MMAs and the factors that need to be taken into consideration by the communities involved. These community-based initiatives are supported by their nongovernment-organisation partners and are part of the Fiji Locally Marine Managed Areas (FLMMA) network, which demonstrates the popularity and effects of community-based resource management practices. However, FLMMA is still striving for efficient and effective MMAs and to make marine resources management more satisfying and meaningful to those involved. In the meantime, FLMMA partners have channelled increased resources into local communities and contributed to resource management as well as poverty reduction in rural communities that depend on marine resources (Aalbersberg et al. 2005:151).

Although most conservation review efforts to date have focused on MMAs' bio-physical and economic features, it is also critical to understand the cultural roles involved because of their influence on resource management decisions and compliance. After all, resource management is about managing the activities of people. As Jacques Weber contends (Henocque and Denis 2001:8), 'Environmental management is not a question of humans' relationship to nature; instead, it is a question of human relations on the subject of nature.'

Cooke and Moce (1995), Muehlig-Hofmann (2008) and Sano (2008) show that management strategies and the level of government participation vary greatly throughout Fiji and depend on the individual fisheries officers, chiefs and communities involved. In some places, people alter their resource-management activities when their social and economic conditions change. In other cases, problems and conflicts arise when community resource managers feel they are treated poorly or with disrespect. The lack of funds and capacity within Government has forced the reliance on the local governance and self-regulation of the coastal communities. However, the CI study shows that with their present structure, skills and resources, local communities alone cannot establish and carry out the management measures needed to mitigate the increasing pressure on their resources. Therefore, effective management of marine resources by community groups needs government support.

Marine resource management in its various forms is undertaken in Fiji's communities. Most of these communities collaborate with partners from non-government organisations (NGOs) and institutions (Veitayaki et al. 2005a, 2005b; Veitayaki 2006; Muehlig-Hofmann 2008; Sano 2008) to establish their MMAs, while others work independently or through local chiefs, officials and academics, or they learn from neighbouring communities and relatives. In many cases, resource management activities are dependent on the ambitions of the communities and individuals involved (Muehlig-Hofmann 2008) and the approach adopted by the group. 


\section{Some cultural features}

The basis of Fijian organisation are the villages that people live in. Villages were originally small, and the main regulators to their size are the minimum viable defence force or workforce or the maximum number that the food supplies will support (Frazer 1973:78-79). Despite continually increasing in size over the years, village composition has remained the same, with each consisting of one or more closely related clans. Clans consist of mataqali, commonly the land-owning units, which include a number of extended families, or tokatoka, that are made up of individual households. From the different mataqali or tokatoka come the chiefs (turaga ni vanua), heralds (mata ni vanua), warriors and planters (bati), fishers (gonedau), priests (bete) and carpenters (mataisau).

The village operates because the different groups (mataqali or tokatoka) within it have specific tasks they are responsible for performing (Seruvakula 2000:21-29). People know who they are and what is expected of them. The sauturaga, for instance, are responsible for maintaining respect and order for the chief and the village. They ensure that all their responsibilities are fulfilled and that the protocol is observed (Capell 1991).

The chiefs and their clansmen are the traditional owners and guardians of the land, waters, resources and people. Previously, Fijians did not attribute monetary value to land or have the concept that land could be bought and sold for personal gain (Farrell 1972:38). This has changed, as land as a commodity is now a major cause of conflict among close family relations. Fortunately, laws and institutions have been put in place to address land issues and other aspects of Fijian affairs.

Customary marine tenure (CMT) is the formal and informal ownership of sea space by a Fijian group ranging from tokatoka to tikina (district) (Calamia 2003). The CMT system is built on local autonomy and self-reliance that controls the use of local marine space and resources. The use and management of customary fishing areas is determined by the group that owns the area. The use of customary fishing grounds by outsiders is permitted, provided access conditions are met. This system is seen by some as a hindrance to economic progress because the indigenous owners of the resources may not support important developments, as they are not convinced the proposed development projects will bring benefits to them.

Indigenous Fijians have exclusive customary fishing rights in their qoliqoli, extending from the coast to the barrier reefs and some offshore reefs. The location and size of the tenured fishing grounds is not based on ecologically optimal management units but on historical developments and societal, traditional and geographic factors. Thus, the size of the fishing ground and the quantity of its resources reflects the owner's historical status and prominence and is not related to the size of the population that depends on it or the boundaries of the ecological region (Muehlig-Hofmann et al. 2005).

Village life has evolved since European contact in 1643. In 1864, the first Melanesian farm labourers were shipped to Fiji because it was believed the local population's custom and kin ties would prevent them from working hard. In subsequent years, some 20,000 Ni Vanuatus, I Kiribati, Tuvaluans, Tokelauans and Solomon Islanders were brought to Fiji (Narayan 1984:23).

In 1874, Fijian chiefs ceded their country to Britain and became subjects of Queen Victoria to formalise the transition to contemporary Fiji. Shifting cultivation, which provided food for consumption and social obligations, was replaced by permanent plantations. The communication lines, health services, education and European goods that became a part of village life in the $1960 \mathrm{~s}$ (Frazer 1973:78-79) continue to transform villages to mirror modernising societies elsewhere. Cash crops, wages and commercial activities are now established in villages throughout the country. 
Decision-making was transferred from the hereditary chiefs and community councils to the government officials and judiciary (Frazer 1973). In addition, individuals and groups became more independent. Fijian villages were no longer limited in size and were influenced by their proximity to urban areas. Furthermore, villagers were attracted to urban life, with its opportunities for higher income and status.

The development expected after attaining political independence in 1970 has not materialised and the country is divided between the urban centres and peripheral rural areas. Political upheaval has hindered the country's social and economic development. After four coups in 20 years, the people are now working with the National Charter for Building a Better Fiji (Daurewa 2008) to redirect development towards sustained peace and prosperity.

Currently, traditional marine resource management promotes improving existing conditions, with the general population regulated to the role of spectator and the state responsible for resource management activities. Intensive and habitual fishing of Fiji's reefs by the ever increasing population using effective and destructive fishing methods is causing extensive damage that is threatening the fishing areas. In Macuata's Qoliqoli Cokovata, the high number of school dropouts adds more pressure to the area's already diminishing marine and terrestrial resources (Bolabola et al. 2006). In these areas, commercial and subsistence fishing are driving people further into deeper and distant offshore areas, increasing their costs and threatening their sources of livelihood and food.

Poaching is common even in MMAs, while destructive fishing practices such as fish drives are still used in Vanua Balavu, Bua and Gau. These harmful fishing methods are blamed for the extensively damaged reefs and the algae and seaweed now dominating some of the coastlines. The pollution and sedimentation associated with poor development practices is also a major threat to customary fishing grounds (Veitayaki 2006). Fiji's hillsides are commonly burned, threatening farmlands, while biodiversity and pesticide use is increasingly affecting the environment. In Vanua Balavu in the Lau Group, the villagers are asking why destructive chemicals are being introduced so freely into the villages when they are so damaging to the environment.

Customary roles and duties are less clear and effective in Fiji today. The traditional tenure system and resource management strategies, for example, experienced gradual erosion due to the impact of 20th century colonisation (Govan 2009:25). While traditional roles and resource-use systems within the communities are still well defined, leadership structures, protocol, respect, practices and beliefs are changing and are increasingly questioned by the people (Vunisea 2002). Moreover, intermarriages and the use of modern equipment have allowed people to fish in areas far away from their home base.

Muehlig-Hofmann (2008) argues that qoliqoli and other traditional systems are unable to independently cope with the rapid exogenous change and hence fail to perform their role in fisheries management; a role others believe they are capable of fulfilling (Anderson and Mees 1999). While there is strong support for the MMA, there are differences about the length of MMA closure, which some say could be alleviated by periodically relaxing activities in MMA (Van Beukering et al. 2007).

Contrary to the customary marine tenure system, the sea and sea floor stretching from the high-water mark belongs to the state (South and Veitayaki 1998). This mixed arrangement has been a source of confusion for more than 130 years (Ruddle 1994; Cooke and Moce 1995) and needs to be the basis of co-management. Since political independence, attempts have been made to return full ownership of the qoliqoli areas to the indigenous owners. In August 2006, in an attempt to resolve the situation, a Qoliqoli Bill was put before the Fiji Parliament that proposed returning all proprietary rights to qoliqoli areas to the identified traditional owners. The Qoliqoli 
Bill caused controversy among the diverse stakeholders, some of whom harboured the idea that it privileged the indigenous Fijian population. According to this group, the legislation undermined responsible community-based resource management as ownership rights are in the hands of the land-owning groups (mataqali) (Muehlig-Hofmann 2008). In addition, issues such as community leadership and responsibility for community resource management efforts need to be appropriately addressed.

Fiji's MMAs are driven by the idea that sustainable healthy living standards and income can only be achieved with properly managed marine environment and fisheries resources. The varying degree of success seen in the more sustainable approach to exploitation pursued over the past decade is indicative of the people's inability to get organised and committed to resource management (Veitayaki 1998; Zann and Vuki 1998). Contrary to the MMAs, many communities are trying to modernise their fishing methods to increase their output. In fact, commercial fishing in rural Fiji has continued to expand and intensify, challenging MMA initiatives undertaken by local communities.

Given the current harvesting capacity, a fisheries resource can easily be exploited beyond sustainable levels. Thus, the precautionary approach to fisheries needs to be implemented at the village level. According to Muehlig-Hofmann (2008), who worked on Gau Island, community challenges can only be met by a strong bond between official agents and communities that is based on continuity, community consensus and trust. This can be achieved if every community has experienced officials working with it to formulate and implement conservation measures, surveillance, compliance, communication, networking, data collection and analysis.

\section{The influence of cultural roles on MMAs in Fiji}

Cultural roles are crucial to the declaration and support of local MMAs. However, they are not effective outside the local community context, where government regulations, policies and legislation are of greater consequence. Maintaining community MMAs is also challenging as the people need to be unanimously convinced that resource management improves their lives. Unfortunately, most of the villagers are unable to sustain their MMAs to realise the benefits because of outside pressure by traders and poachers, whose activities compromise the effectiveness of MMAs. As a result, Fiji's rural MMAs are vulnerable and targeted by poachers who consider these spots premium fishing grounds.

The establishment of MMAs in local communities was supported by traditional institutions and customs that are now eroding. Traditional protocols, for instance, are not strongly followed, while the enforcement of noncompliance within a community has changed. At times, traditions are abused for the benefit of a limited few. Traditional relations and ties are at times used to access the resources of rural communities. For example, some commercial operators present a sevusevu (the traditional offering of kava to announce arrival and welcome visitors) worth US\$15 and earn between US $\$ 150$ and $\$ 1500$ from the fisheries products caught in their host's qoliqoli. In other instances, unscrupulous operators establish markets in rural areas to entice people to relax their management activities. This is the reason why effective communication is critical.

MMAs have greatly benefited coastal communities. People have realised the critical importance of maintaining the health and productivity of their fishing grounds and how these are related to and affected by all the ecosystems around them. Through training, the villagers are realising their responsibilities as stakeholders who depend on these resources for their livelihoods and who need to sustain their resources for current and future sustenance. They see the need to make the right choices for their children. In Verata, the permanent MMA is now surrounded by an area that is allowed to be fished whenever the villagers want. Under this arrangement, 
a portion of the MMA is always permanently closed, providing seeds for the recovery of the fished areas.

Communities now understand the need for an integrated resource management approach and have adopted the ecosystem-based method for managing their resources. This method is the basis of resource management activities in Verata, Muaivusu, Kubulau and Gau. People involved with MMAs now enjoy better lives; they are spending less time to get more resources and are earning more money than before. Fishing is now conducted in areas previously avoided and the abundance of fisheries resources and the reappearance of resources that have not been seen in recent times have been noticed. In general, communities are realising the recovery of their fisheries resources and the marine environment. This success in marine resource management is being extended to other areas of people's lives and responsibilities. The people are looking for alternative sources of income and are searching for better ways of using their natural resources. People's living conditions are being improved with the assistance of conservation partners through sustainable tourist activities, fisheries development, land use and forestry activities and the sale of traditional art and crafts.

The community-engagement approach in MMAs improved the management of marine resources and boosted rural-development activities. Villagers have enhanced their incomegenerating activities and established new sources of income such as mat making and ecotourism. Some conservation efforts have been rewarded with assistance such as village halls, outboard punts and engines that were given to communities in Ono and Navakavu, and trust funds that have been set up for communities such as Verata and Kubulau.

Socially, the villages, tikina and islands are working together with a better sense of purpose and cohesion. Social units have been strengthened, and district meetings (bose) and church services (lotu ni vanua) are now operating. The social institutions are revitalised and strengthened through development assistance that has allowed regular consultation and meetings. The social units are now more relevant because they are supporting the people's development aspirations. Community leaders are supported by being involved in consultative meetings and training, and visit other communities to widen their experiences and expand on their ideas.

Some of the community groups are earning steady incomes from their resource management activities. In Kubulau, there is a scholarship program for the villagers' children attending secondary and tertiary institutions, while the villagers now host divers from Lautoka hotels in their MMAs. In addition, the development partners are collecting money to support the protection of the marine environment. In many of the operating MMAs, assistance from the development partners is offered to the villages, village schools, kindergartens and health centres.

Studies in Fiji supported the increased income earned from resource management activities. Since 2006, the women of Vanuaso Tikina in Gau have earned about US\$500 per month from the sale of their mats in Suva. In Vanuaso village, the youth opened a store that had not operated for more than 20 years, and in the villages of Malawai and Lekanai, the youth groups now own cattle farms that provide for the communities' ceremonial obligations. These initiatives demonstrate the link between economic development and care of the environment. The people are learning that they need to take care of their environmental resources because their lives depend on it.

\section{Challenges}

Unfortunately, many improvements are needed to ensure the effective operation of MMAs in Fiji. Many of these improvements involve the incorporation of traditional practices and cultural roles into contemporary resource management plans. In many cases, for instance, not everyone 
in the village is aware of what is going on, with resource management decisions made by a small group including the chief. In such cases, the involvement of the larger group depends on how well the message and decision is disseminated through the community. In other instances, there is an incorrect assumption that the entire community is involved. This study highlighted that this is sometimes not the case and that wrong assumptions compromise community support.

The importance of effective communication is also crucial to a community's resource management efforts. The strength of the traditional system is based on everyone observing the group's decision. This is only effective in cases in which the entire community is continually reminded of its resource management activities. Successful communication requires regular visits and follow-up activities so the stakeholders are consulted and kept informed on issues such as the ownership of MMAs and what is being and still needs to be done.

The 2009 indictment of the high chief of Macuata Province for authorising his honorary fish wardens to confiscate fish catches from fishers allegedly illegally fishing in his domain illustrates the need for government support to sustain customary resource management practices. The Fiji Government needs to put in place legislation to protect community-based resource management initiatives. Moreover, the Government needs to promote resource development and resource management. At present, the Government's emphasis on fisheries development is exemplified by the requirement that its support is subject to an applicant's possession of a fishing licence, which communities observing MMAs do not have.

Poaching is prevalent in rural communities because the Government has not assisted those who are least able to defend their resource management decisions. Without the local resources required for enforcement of environmental regulations, poaching will continue to occur. In many cases, the people's resolve to maintain their MMAs is badly undermined by the extent of poaching. This forces the community to relax its management activities so it may receive some benefit from its own MMA. These communities feel it is pointless to refrain from using their MMAs if outsiders are the primary beneficiaries. Poaching is stealing and should be treated seriously by the Government, which also needs to acknowledge that commercial fishers and businesses are supporting people that are stealing from rural communities. Many of these are the same communities the Government should be assisting to improve their living conditions while sustainably utilising their resources.

Poaching also tempers the effectiveness of MMAs, providing an inaccurate reflection of the recovery of the resources. An accurate resource-recovery picture is necessary to convince people that the MMAs work. In some cases, communities give up their MMAs because others are benefiting from their sacrifices. In these cases, the people ignored the effort put into the establishment of the MMAs and the benefits they have been witnessing.

Communities practising resource management are under continuous pressure to relax their management plans because their MMAs are a potential source of instant income. In many villages, there are limited opportunities to earn an income to pay for necessities and responsibilities, so the MMAs are seen as the community's last resort.

Sadly, people in rural areas are seldom given ample time to prepare for their financial obligations. Rural people therefore regularly turn to their MMAs to secure much-needed income. Hurriedly organised village income-earning activities such as collections and contributions are often conveniently supported by the arrival of commercial operators who easily convince the people to relax their MMA activities and earn the needed money from the sale of their products.

People in rural areas today need money to pay for food, electricity and transport to harvest their natural resources, as well as for their community obligations, church contributions and education. They periodically open their MMAs to pay for some of these obligations. In order 
for people to treat their MMAs seriously, the villagers need to have alternative avenues for generating income. People also must note that once an MMA is relaxed, it is difficult to re-close the site or commit to another MMA. In many instances, local fishing businesses, backed by middlemen in the cities, have sprung up in villages with MMAs to buy fish from the villagers. These commercial ventures are often non-sustainable.

Many communities, perceiving the MMAs as belonging to their partners, are weakly supportive of their resource management activities. This perception is related to the role played by the partners in the initial empowerment of communities and their declarations of MMAs. Unfortunately, people in these areas expect compensation for their contributions to MMAs, wait for directives from the partners and at times threaten the MMAs if their demands are not met. Obviously, these communities have not been convinced about their ownership of their MMAs, and so it is easier for them to trade their MMAs for much-needed goods or income.

Shifting demands from local communities of their partners are common. In some cases, the local people expect their partners to provide for their evolving needs even though they themselves are not committed to the MMAs and the partners have met all of their promised support. There is a need for local people to see their partners as generous and dedicated people who want to assist them and not as sources of unlimited riches to be used. The work in Vanuaso Tikina in Gau Island (Veitayaki et al. 2005a, 2005b) proves that local communities can take ownership of their MMAs if they are allowed ample time to make the determinations. Thus, long-term engagement of local communities is crucial to the process of establishing and maintaining effective MMAs.

Village meetings are regularly conducted but they are not all well organised and not well attended. The meetings are held mostly for the men who, it is assumed, will inform their women. Even if the women were expected to or wanted to attend, meetings are often held at times when the women are busy preparing breakfast and attending to the children. Minutes of the meetings are not well kept so reiteration of the discussions that took place and decisions made is commonly inconsistent and disorganised and often contradictory. Moreover, follow-up activities are not regularly communicated to the villagers, who are then left in the dark about what the village or district is undertaking and their expected contribution.

The community system of representation is ineffective due to poor communication and organisation. Without full knowledge of the undertaking, community members will not be fully engaged in their MMAs. The lessons from the training workshops, for instance, are not well relayed to the communities, while the information from the communities is not accurately reported to the partners. Local representatives do not consult the villagers before attending the various meetings where they speak for the community, while the local representatives, who are expected to articulate the meeting's decision in the community, do not share the information. Written reports are often in English or appear in formats that the villagers have problems understanding or using. Hence, people generally have only limited knowledge of the events impacting their community, while the lack of organised communication hinders the collective effort needed for operating effective MMAs.

Traditional leaders need to regularly seek advice on issues in which they are not well versed. Community leaders should guide and lead their people into the modern world, as well as look after the interests of their future generations. It is here that well-organised community-based committees can play an important advisory role to the traditional leaders. In fact, many local communities have formed committees to look after both resource management and development issues. These committees should be encouraged because of the complexities of contemporary community issues. Some of the issues that today's communities have to address and be trained 
for are good leadership and governance, development planning and implementation, sustainable use of resources and improvement of livelihood.

The changing of the guard is an unstable period in many local communities. Some people take advantage of this time to seek the relaxation of their community's resource management activities. In some cases, the MMAs are relaxed when a chief dies or shortly after when the community is asked to host a gathering for which the people are not adequately prepared. In other cases, the new chief's vision on the MMAs is different from the last chief's, so the community has to re-adjust its resource management activities accordingly.

It is important to note that local commitment is critical to the success of MMAs. This is due to the reliance people have on the resources and the impacts these resources have on people's livelihoods. Nevertheless, the long-term commitment to sustainable development is difficult to achieve under current conditions. People often only seek the fast money and instant gratification that they will get for exploiting their resources. In comparison, long-term conservation is not as attractive because people need to pay for essentials and assistance now. The few options available for earning an income make people look to their MMAs as a first and last resort to earn money.

The last challenge is the conflict and differences that arise in local communities. Some villagers do not fully comply with their community's resource management activities because of long-standing community conflicts and rivalries. These differences are deep rooted and difficult to solve as they are based on traditional and historical reasons often associated with customary roles. Such conflicts can hinder MMA operation unless there is effective leadership and measures to amicably resolve such differences.

\section{The way forward}

MMAs are one of the traditional resource management practices that have the potential to benefit local communities. However, the MMAs' effectiveness can only be realised if the issues that hinder their establishment and maintenance are addressed. This requires the assessment and strengthening of the cultural roles that are an integral part of these MMAs.

Good and visionary leadership is required in local communities where the bulk of the population has never left the village and is unfamiliar with the contemporary challenges it must address. This leadership is needed to ensure that the interests of all of the people, including future generations, are protected, and that they are allowed the opportunity to thrive in a contemporary setting. Leaders need to convince their people that protecting their food sources and their natural resources are the bulwark against starvation and poverty and the best safeguard for the wellbeing of future generations.

Governance and leadership issues need to be addressed to improve community living standards in general and enhance marine resource management in particular. The Fijian administration at all levels needs to ensure that Fijians look after their interests and responsibilities. In terms of organisation, the church is already showing the way forward. The challenge is to extend this success into all facets of life in the local communities.

People need to better organise village meetings where the minutes and records must be properly kept and tasks followed through to completion. The population must be regularly reminded of resource management decisions. For example, during village meetings the Turaga ni Koro (village headmen) must broadcast all of the village activities. This follow-up action is crucial for ensuring that the resource management decisions are endorsed and supported by all community members.

Villagers should improve the maintenance and management of their records. Community 
discussions, decisions and activities should be accurately recorded both for reference and for monitoring the changes. These community reports should be regularly lodged with the community's development partners and the Government so that the villagers' positions on issues are clearly known and their activities documented.

Villagers need to focus on long-term planning. Many of these initiatives, such as those addressing income-generating activities, sustainable development, climate change and altered habitats, require strategic planning and prudent implementation. Development activities need to be identified and undertaken to bring about better results and life for all.

Capacity building is critical, as new solutions are required to deal with the contemporary challenges that are unusual in traditional systems and therefore must be learned and mastered quickly. In many cases, the chiefs can better use their appropriately trained people who, if in positions of responsibility, need to diligently perform their duties in a transparent and trustworthy manner.

Communities need to make resource management decisions because their resources are unlikely to support their ever increasing demands within a continually degrading environment. Although decision making is the privilege of a few, such as chiefs and elders, their decisions are critical and will influence the quality of life of their people now and into the future. These decisions must be made carefully as they must be adhered to by all. For example, critical resource management decisions have to be endorsed and supported by all stakeholders and should be regularly reviewed and effectively communicated to ensure that the village's resource management commitments are known and honoured by everyone.

At the same time, community partners need to fulfill their long-term obligations. The partners should understand that their community counterparts alone cannot pay the expenses required for looking after the MMAs. Some communities are complaining about the irregularity of their partner's visits and are feeling abandoned. In some areas, community partners are perceived as uninterested in the individual sites because they now only work through the FLMMA network. As it was put to us, FLMMA is now the self-serving focus of Fiji's MMAs that is benefiting from using the individual sites that are otherwise left on their own after their initial empowerment.

Communication within the village and all levels of Fijian administration needs to be improved. Village decisions must be adequately recorded and then shared with everyone involved. Traditional communication protocol is not effectively informing all the stakeholders, who use this breakdown in communication as an excuse not to adhere to the group's decisions.

The Fijian Government, particularly the Fisheries Division, must lead resource management at the local, national and international levels. If MMAs are to succeed, the Government needs to recognise their importance and render its support through appropriate policies, legislation, plans and strategies. By enforcing existing laws, legislation can empower local communities to protect their resources. For example, fishing licence numbers should be easily identified by being clearly marked on the side of fishing vessels. Local community members can curb lawlessness by submitting the licence numbers of the boats fishing in their waters to the Government for identification. Those found violating the Fisheries Act must be penalised harshly so that others are discouraged from acting illegally.

Poaching can be better controlled if licence current conditions are enforced. Anyone selling fish must have a licence, which cannot be transferred. Department of Fisheries officials accompanied by the police must man all of Fijis main docks to inspect fishing licences. People need to fish in their own designated areas and be encouraged to report suspicious events that 
may be in violation of the law to the authorities. Those found in violation of their licences should be dealt with harshly.

MMAs need to be relevant to local communities, which must incorporate them into their community initiatives. To allow for this, external partners must genuinely involve local people in project activities that are meaningful to the community. This requires that villagers be engaged in activities that are significant enough to convince them of the importance of resource management to the improvement of their lives.

Given the societal changes taking place, long-term commitment to sustainable development is required in rural communities and across the land. Sustainable development is related to the tradition of relying on the resources available in an area and the need to look after the welfare of the current as well as future generations.

The CI study has highlighted many useful lessons that must now be taken into consideration in the maintenance of effective MMAs. Of course, many of the cultural roles and influences have to be properly addressed. These issues must be amicably addressed because the children of current and future generations in Fiji and other Pacific Islands expect their parents and elders to be good role models who carefully balance their development activities with their maintenance of the integrity and health of their environmental systems. This is a big responsibility because life in years to come will depend on the decisions made by the current generation. Fortunately, customary and traditional practices already provide the basis for sustainable development and effective MMAs. What is needed is to ensure that communities are prepared for the realities they will face in the future and a commitment to address the associated challenges. 


\section{References}

Aalbersberg, B., Tawake, A. and Parras, T. 2005. Village by village: Recovering Fiji's coastal fisheries. In: UNDP, UNEP, WRI, World Resources 2005 - The wealth of the poor: Managing ecosystems to fight poverty, pp. 144-152. World Resources Institute, Washington, DC.

Anderson, J.A. and Mees, C. 1999. The performance of customary marine tenure in the management of community fishery resources in Melanesia. Final Technical Report to the UK Department for International Development, MRAG Ltd, London.

Bolabola, A.,Veitayaki, J., Tabunakawai, K. and Navuku, S. 2006. Socio economic baseline survey of Qoliqoli Cokovata area - District of Mali, Dreketi, Sasa and Macuata, Vanua Levu. Ecosystembased management project. Unpublished WWF report, Suva.

Calamia, M. 2003. Expressions of customary marine tenure and environmental entitlements: A case study involving common property regimes in a Fijian outer island group. Unpublished $\mathrm{PhD}$ thesis, University of Colorado.

Capell, A. 1991. Fijian dictionary. Obtainable from the Fiji Government Printer.

Cooke, A. and Moce, K. 1995. Current trends in the management of qoliqoli in Fiji. SPC Traditional Marine Resources Management Knowledge Information Bulletin 5:2-7.

Daurewa, A.W. 2008. There is no such thing as a poor Fijian. Fiji Times Online Wednesday 29 October.

Farrell, B.H. 1972. The alien and the land of Oceania. In: Ward, R.G. (ed), Man in the Pacific Islands, pp. 34-73. Oxford University Press, London.

Frazer, R. 1973. The Fijian village and the independent farmer. In: Brookfield, H.C. (ed), The Pacific in transition: Geographical perspectives on adaptation and change, pp. 75-96. Martin's Press, New York.

Govan, H. 2009. Status and potential of locally-managed marine areas in the South Pacific: Meeting nature conservation and sustainable livelihood targets through wide-spread implementation of LMMAs. SPREP/WWF/WorldFish-Reefbase/CRISP. Online at http://www.crisponline.net/ Portals/1/PDF/0904_C3A_Govan_MMAs.pdf

Henocque, Y. and Denis, J. (eds), 2001. A methodological guide: Steps and tools towards integrated coastal management. IOC Manuals and Guides No. 42. UNESCO.

Muehlig-Hofmann, A., Veitayaki, J., Polunin, N.V.C., Stead, S. and Graham, N.A.J. 2005. Community-based marine resource management in Fiji - from yesterday to tomorrow. Proceedings of the 10th International Coral Reef Symposium 2004 In: 10th International Coral Reef Symposium 2004, 28 June - 2 July 2004, Okinawa, Japan.

Muehlig-Hofmann, A. 2008. Ownership of Fijian inshore fishing grounds: Community-based management efforts, issues of traditional authority and proposed changes in legislation. Ocean Yearbook 22:291-321.

Narayan, J. 1984. The political economy of Fiji. South Pacific Review Press, Suva.

Ruddle, K., 1994. Traditional marine tenure in the 90s. In: South, G.R., Goulet, D., Tuqiri. S., and Church, M. (eds), Traditional marine tenure and sustainable management of marine resources in Asia and the Pacific, pp. 6-45. International Ocean Institute - South Pacific, Suva.

Sano, Y. 2008. The role of social capital in a common pool resource system in coastal areas: A case study of community-based coastal resource management in Fiji. Unpublished PhD thesis, The Australian National University.

South, G.R. and Veitayaki, J. 1998. The constitution and indigenous fisheries management in Fiji. Ocean Yearbook 13:452-466.

Seruvakula, S.B. 2000. Bula Vakavanua. Institute of Pacific Studies, Suva.

Van Beukering, P.J.H., Scherl, L.M., Sultanian, E., Leisher, C. and Fong, P.S. 2007. Case study 1: Yavusa Navakavu locally managed marine area (Fiji). The role of marine protected areas in contributing to poverty reduction. http://www.prem online.org/archive/19/doc/Country\%20 Report\%20Navakavu\%20_Fiji_.pdf 
Veitayaki, J. 1998. Traditional and community-based marine resources management system in Fiji: An evolving integrated process. Coastal Management 26(1):47-60.

Veitayaki, J. 2006. Caring for the environment and the mitigation of natural extreme events in Vanuaso Tikina, Gau Island, Fiji: A self-help community initiative. Island Studies Journal 1(2):239-306.

Veitayaki, J., Tawake, A., Bogiva, A., Radikedike, P., Meo, S., Ravula, N., Vave, R. and Fong, S.P. 2005a. Partnerships and the quest for effective community based resource management: Mositi Vanuaso Project, Gau Island, Fiji. Journal of Pacific Studies 28(2):328-349.

Veitayaki, J., Tawake, A., Bogiva, A., Radikedike, P., Meo, S., Ravula, N., Vave, R. and Fong, S.P. 2005b. Addressing human factors in fisheries development and regulatory processes in Fiji - The Mositi Vanuaso experience. Ocean Yearbook 21:289-306.

Vunisea, A. 2002. Community-based marine resource management in Fiji: The challenges. SPC Women in Fisheries Information Bulletin 11:6-9.

Zann, L.P. and Vuki, V.C. 1998. Subsistence fisheries in the South Pacific. In: Fisheries and marine resources, pp. 103-114. Papers presented at Symposium 8, 8th Pacific Science Inter-Congress. The University of the South Pacific, Fiji. 13th-19th July, 1997. Marine Studies Technical Report No. 98/3. The University of the South Pacific, Suva. 